\title{
Bukan Sekedar Pelipur Lara: Promosi Pariwisata dalam Dongeng “Nusantara Bertutur" Koran Kompas 2019
}

\author{
I Nyoman Darma Putra ${ }^{*}$, Eva Lailatur Riska ${ }^{2}$ \\ ${ }^{1,2}$ Sastra Indonesia, Fakultas Ilmu Budaya, Universitas Udayana, Denpasar, 80113, Indonesia \\ idarmaputra@yahoo.com ${ }^{2 *}$,e.lailaturriska@gmail.com²
}

Sastra dan pariwisata sejak lama mempunyai hubungan erat namun kurang mendapat perhatian dari para peneliti. Penelitian ini bertujuan untuk mengkaji aspek narasi pariwisata dalam dongeng Nusantara Bertutur yang dimuat koran Kompas sepanjang tahun 2019. Data dipilih secara selektif dari seluruh dongeng yang dimuat setiap hari Minggu. Dari sebanyak 49 dongeng yang dimuat sepanjang 2019, 25 di antaranya mengandung narasi tentang daya tarik, perjalanan, atau aktivitas wisata. Data dianalisis dengan pendekatan sastra pariwisata dengan penekanan pada tema, latar, tokoh, dan aspek pariwista yang dinarasikan dalam dongeng. Hasil penelitian menunjukkan bahwa dongeng Nusantara Bertutur lebih dari sekadar hiburan, karena juga mengandung lukisan keindahan alam (matahari terbit, keindahan danau, pantai, alam bawah laut, dan alam perdesaaan); aneka ragam kuliner Nusantara; dan narasi tentang tradisi atau ritual Nusantara seperti Upacara Kasada dan Hari Raya Karo di Bromo (Jawa Timur), karnaval Sigale-gale di Danau Toba, serta Jathilan di Magelang Jawa Tengah. Artikel ini menawarkan pemahaman baru bahwa dongeng tidak saja sarat cerita dengan pesan etika dan moral atau pelipur lara tetapi juga mengandung promosi daya tarik wisata dan pengenalan aneka tradisi dan budaya Nusantara kepada anak-anak.

Kata kunci: pelipur lara, dongeng nusantara bertutur Kompas, sastra pariwisata

\section{Not Just an Empty Entertainmet: Promotion of Tourism in the Fairy Tale of "Nusantara Bertutur" in Kompas Newspaper 2019}

Literature and tourism have long had a close relationship, but researchers of the fields have paid little attention on them. This study aims to examine aspects of the tourism narrative in the Nusantara Bertutur (Fairy Tales of the Archipelago) published by Kompas on its Sunday edition throughout the year of 2019. The data were selected purposively from all fairy tales published every Sunday. Of the 49 fairy tales published, 25 of them contain narratives about travelling, tourist attractions or activities. The data were analyzed with a tourism literary approach with an emphasis on the theme, setting, and tourism aspects narrated in fairy tales. The results of the study show that the fairy tales of Nusantara Bertutur are more than just entertainment, because they also contain paintings of natural beauty (sunrise, beautiful lakes, beaches, underwater nature, and rural nature); various kinds of Indonesian cuisine; and narratives about the traditions or rituals of the archipelago such as the Kasada Ceremony and Karo Holiday in Bromo (East Java), the Sigale-gale carnival on Lake Toba, and Jathilan in Magelang, Central Java. This article offers a new understanding that fairy tales are not only full of stories with ethical and moral messages or solace but also contain the promotion of tourist attractions and the introduction of various traditions and cultures of the archipelago to children.

Keywords: solace, fairy tales of Nusantara Bertutur by Kompas, tourism literature

Received: July 19, 2021; Accepted January 31, 2022; Published February 7, 2022 https://doi.org/10.31091/mudra.v37i1.1600

(C) 2021 The Author(s). Published by Pusat Penerbitan LP2MPP Institut Seni Indonesia Denpasar. This is an open-access article under the CC BY-NC-SA license 


\section{PENDAHULUAN}

Sastra dan pariwisata sudah lama saling memberi dan menerima untuk perkembangan satu sama lain. Misalnya, banyak daya tarik pariwisata yang berbasis sastra termasuk seni pertunjukan Tari Kecak Bali yang mengangkat lakon dari epos Ramayanan, banyak usaha pariwisata yang mengangkat cerita rakyat sebagai bradning atau merk usaha seperti cerita rakyat Mandalika yang dijadikan nama resort wisata di Lombok (Putra, 2019; 2020). Daerah Belitung terkenal sebagai daya tarik wisata karena novel Laskar Pelangi (2005) dan film berjudul sama (Liputan6.com, (2017), begitu juga dengan objek wisata makam Sitti Nurbaya di Padang (Ferdinal, Eros, dan Rizano 2019; Endriani, 2015; Kompas.com 2008).

Sebanding dengan itu, banyak tempat wisata yang memberikan inspirasi kepada sastrawan untuk mencipta misalnya novel Aku Cinta Lovina (2017) karya Sunaryono Basuki KS dan Cintaku di Lembata (2016) karya Sari Narulita. Lovina adalah destinasi wisata pantai di Bali Utara, sedangkan Pulau Lembata adalah pulau kecil di wilayah Nusa Tenggara Timur yang terkenal akan alam pantai, tradisi, dan aktivitas tradisional berburu ikan paus (Artawan 2020; Wiyatmi, 2020). Tentang hubungan simbiosis mutualistik antara sastra dan pariwisata pernah ditegaskan oleh Putra $(2017$; 2019) seperti ini.

"Sastra dan pariwisata [...] mempunyai hubungan resiprokal terlihat dari kenyataan bahwa pariwisata ikut terlibat dalam proses kreatif seorang penulis dengan memberikan sumbangan inspirasi terhadap penciptaan karya sastra. Begitu pula sebaliknya, sastra telah banyak memberikan kontribusi dalam hal mempromosikan tempat-tempat pariwisata." (Putra, 2017: 2).

Pariwisata seringkali menjadi latar sebuah cerita sekaligus dapat menjadi tema utama dalam sebuah karya sastra. Pemilihan diksi, frasa, maupun kalimat yang mengandung aspek pariwisata sering kali muncul dalam karya sastra. Karya inilah, pada akhirnya disebut sebagai cerita perjalanan atau sebagai produk sastra pariwisata. Menurut Thompson (2011) cerita perjalanan bertujuan melaporkan dunia yang luas meliputi orangorang dan tempat-tempat yang asing atau yang unfamiliar (Thompson, 2011:10). Kajian tentang kisah perjalanan ke destinasi wisata dilakukan Jeffrey Melton (2002) dengan membahas kisah-kisah perjalanan penulis Mark Twain, Amerika dari akhir abad ke-19. Dalam buku Travel Books, and Tourism: The Tide of a Great Popular Movement, Melton membahas hampir semua karya Twain, seperti The Innocents Abroad dan
Life on the Mississippi. Menurut Melton, jenis tulisan kisah perjalanan karya Mark Twain secara baik menjadikan Mark Twain sebagai 'travel writer' dan sebagai 'turis' (2002:xv).

Melton juga menunjukkan hubungan simbiosis mutualisme antara karya sastra dan pariwisata. Menurut melton, calon wisatawan membaca buku-buku Mark Twain tentang suatu tempat sebelum mereka pergi sehingga wisatawan yang well informed (sudah memiliki informasi) itu bisa menikmati tempat itu dengan lebih baik, daripada kalau kepala mereka kosong informasi. Selain itu, kisah-kisah perjalanan Mark Twain juga dibaca oleh pembaca Ameriak yang karena alasan ekonomi tidak mampu berlibur sehingga dengan membaca buku itu mereka menjadi tahu informasi dan suasana di destinasi wisata itu. Karena bukunya dibaca dalam konteks dan oleh pembaca berorientasi turis, maka Mark Twain pada akhri abad ke-19 di Amerika lebih dikenal sebagai travel writer daripada novelis (Melton, 2002:1).

Kajian Melton merupakan salah satu karya awal yang mendorong munculnya kritik sastra pariwisata. Pada masa berikutnya, kajian sastra pariwisata oleh ahli sastra dan kajian pariwisata sastra oleh penekun studi pariwisata semakin bermunculan, seperti The Literary Tourist: Readers and Places in Romantic and Victorian Britain (2006) diedit oleh Nicola J. Watson, Literary Tourism and Nineteenth-Century Culture (2009) juga oleh Nicola Watson, dan buku yang bertolak pariwisata sastra yang bertolak dari studi pariwisata berjudul Literary Tourism: Theories, Practice and Case Studies (2019) diedit oleh Ian Jenkins dan Katrín Anna Lund. Artikel-artikel juga bermunculan di jurnal yang membahas sastra pariwisata (dilakukan oleh ahli sastra terhadap pariwisata) atau pariwisata sastra (dilakukan oleh ahli pariwisata terhadap sastra).

Di Indonesia, pariwisata sastra dan sastra pariwisata merupakan pendekatan yang relatif baru (Putra 2017; 2020). Para ahli sastra di Indonesia yang tertarik pada pendekatan baru ini tahun 2020 berhasil menerbitkan kumpulan karangan bertajuk Sastra Pariwisata (2020) yang disunting oleh trio Novi Anoegrajekti, Djoko Saryono, I Nyoman Darma Putra. Buku ini memberikan inspirasi untuk kajian sastra atas tema-tema pariwisata dan juga kajian pariwisata yang berkaitan dengan sastra, seperti "Aku Cinta Lovina: Peran Sastra dalam Mempromosikan Pariwisata Bali Utara" (Artawan 2020). Sebelum itu, juga patut dicatat pendukung munculnya sastra pariwisata seperti tulisan "The Use of Legend in Tourism: Case Study of Si Pitung from Indonesia" (2018) oleh Yostiani Noor Asmi Harini dan buku Buku Panduan Pengembangan Wisata Sastra Siti 
Nurbaya (2019) karya Ferdinal, Donny Eros, dan Gindho Rizano.

Eksplorasi pariwisata maupun perjalanan dalam karya sastra dilakukan oleh sejumlah penulis karya sastra termasuk di dalamnya adalah penulis sastra anak berupa dongeng. Sarumpaet (1976: 21) mengemukakan bahwa "sastra anak adalah karya sastra yang dikonsumsi anak dan diurus serta dikerjakan oleh orang tua. Bentuk sastra anak ini disajikan dalam berbagai genre, seperti puisi, cerpen, novel, dan drama." Sastra anak yang paling tua namun tetap lestari sampai sekarang adalah dongeng, cerita rakyat yang dituturkan secara lisan sebagai penghibur anak-anak menjelang tidur.

Selama ini, kajian atas dongeng atau cerita rakyat dilakukan untuk membahas nilai-nilai karakter bangsa (Karmini, 2020; Suardika dan Hafid, 2021; Laksmita Sari 2019a), kajian kebahasaan dalam dongeng (Aryani 2020), dan kajian cerita rakyat sebagai Bagian ari tradisi lisan untuk sumber inspirasi penciptaan novel (Putra, 2011; Harini 2012). Laksmita Sari dan Putra (2020) menganalisis secara komparatif cerita rakyat Bali Aga (Bali Utara) dengan Ainu (Jepang Utara) dengan titik berat bagaimana tema-tema pelestarian alam dilukiskan dalam tradisi lisan kedua masyarakat tersebut Sementara itu, Laksmita Sari, Putra, dan Giri (2020) menggali aspek gastronomi dalam cerita rakyat Ainu Jepang. Selain menekankan aspek hiburan dongeng atau cerita rakyat, semua penelitian tersebut juga melakukan kajian tematik pengetahuan sosial budaya dalam dongeng atau cerita rakyat yang dijadikan objek kajian. Penelitian ini inspiratif untuk diteruskan dengan mengkaji tematik pariwisata dalam dongeng-dongeng modern Nusantara. Yang dimaksud dengan dongeng modern Nusantara adalah dongeng baru yang diciptakan untuk dipublikasikan di media massa dan dituturkan di depan publik atau direkam untuk diunggah di sosial media seperti Youtube. Banyak dongeng modern yang mengisahkan keindahan tempat dan aktivitas berlibur sehingga dimensi pariwisatanya sangat kental. Tema pariwisata menjadi warna baru dongeng Indonesia yang tampak dari dongeng-dongeng Nusantara Bertutur.

Artikel ini membahas aspek pariwisata dalam dongengdongeng Nusantara Bertutur yang dimuat koran Kompas edisi Minggu sepanjang tahun 2019. Kajian difokuskan pada seperti apa dongeng menarasikan aspek pariwisata dalam dongeng, tema yang diangkat, gambaran sosial budaya tokoh-tokohnya, latar cerita, serta apa makna tema dan latar tersebut diungkapkan dikaitkan dengan dinamika sosial budaya Indonesia dewasa ini. Artikel ini hendak menawarkan cara inovatif mengkaji dongeng.

\section{METODE PENELITIAN}

Penelitian ini menggunakan metode kualitatif deskriptif kritis dengan menganalisis teks dongeng yang dikumpulkan dari rubrik "Nusantara Bertutur" Kompas sepanjang 2019. Pemilihan tahun 2019 dilakukan karena penelitian dilakukan pada tahun 2019, dan kebetulan untuk tahun itu semua dongeng yang dimuat bisa dikumpulkan dengan lengkap. Sepanjang tahun 2019, koran Kompas memuat 49 dongeng dalam rubrik Nusantara Bertutur. Keseluruhan teks dongeng ini merupakan populasi data penelitian. Sampelnya dipilih secara purposive (berdasarkan tujuan) yaitu dongengdongeng yang bertema kepariwisataan. Pemilihan itu dilihat dengan pembacaan teks dongeng dengan memperhatikan latar cerita, aktivitas tokoh, dan isi keseluruhan yang berkaitan dengan kepariwisataan. Dari populasi itu terpilih 25 cerita yang mengandung tematik kepariwisataan. Cerita-cerita inilah yang kemudian dikaji dengan pendekatan sastra pariwisata. Kajian sastra pariwisata, menurut Putra (2019; 2020:114) ada empat yaitu, (1) kajian karya sastra bertema kepariwisataan, (2) kajian destinasi wisata berbasis sastra baik yang berkaitan dengan literary places (tempat yang berkaitan dengan sastrawan) maupun literary figure (termasuk sastrawan atau tokohtokoh cerita), (3) peristiwa atau event atau aktivitas sastra, dan (4) alih wahana sastra yang mengandung nilai promosi pariwisata. Kajian sastra pariwisata bisa juga mengombinasikan keempat area kajian itu, dan tidak tertutup untuk kajian tematik lain sesuai dengan objek yang kajian yang ada. Dalam artikel ini, kajian terhadap dongeng Nusantara Bertutur dilakukan berdasarkan emapt pendekatan itu, terutama pada kajian tematik dan literary places khususnya yang berkaitan dengan latar daerah pariwisata pada dongeng yang dikaji.

\section{SEKILAS TENTANG DONGENG NUSANTARA BERTUTUR}

Dongeng dan tradisi mendongeng sejak lama dikhawatirkan akan lenyap ditelan kemajuan zaman. Nyatanya, dongeng dan mendongeng berkembang di era teknologi digital dewasa ini. Alih-alih lenyap, dongeng-dongeng justru hadir semarak dalam bentuk buku cetak, terbit di surat kabar, dan dibagikan dalam media sosial seperti facebook dan instagram, baik dalam bentuk tertulis atau rekaman video. Situs Youtube juga banyak memuat video mendongeng dari berbagai Nusantara. Link-link dongeng di tersebut juga dengan mudah dibagi di media sosial lainnya.

Praktik mendongeng juga berkembang, tidak saja sebatas di ruamh-rumah, tetapi di sekolah dan tempat 
umum seperti pertokoan. Dongeng yang dimuat di Kompas juga didongengkan oleh Paman Gery dan publik bisa menyimaknya lewat Instagram @paman_gery. Kemajuan tradisi mendongeng dalam bentuk dan konteks baru ini sangat berutang budi pada teknologi digital. Tanpa kemajuan dunia digital, tidak mungkin kehidupan dongeng bisa seperti sekarang.

Media massa nasional Kompas juga memberikan perhatian khusus pada kehidupan dongeng. Koran Kompas setiap minggu membuka rubrik Dongeng Nusantara Bertutur dimuat dalam halaman iklan Klasika. Artinya, pembaca yang melihat iklan akan bisa melihat dongeng, sementara pembaca dongeng (khususnya orang dewasa) akan melihat aneka iklan. Di rubrik dimuat dongeng karya baru dengan ilustrasi yang menarik. Disebutkan dongeng baru karena dia berbeda dengan dongeng-dongeng lisan warisan budaya Nusantara. Kalau dongeng warisna bersifat anonim, dongeng di Kompas tertera jelas nama penulisnya. Hadir dengan nama penulis, mengisahkan cerita masa kini, menggunakan bahasa Indonesia, dimuat di media massa merupakan beberapa ciri dongeng modern. Walaupun berbeda, modern atau konvensional, keduanya memiliki tujuan sama yaitu memberikan pendidikan dengan menghibur, atau memberikan hiburan dengan mendidik.

Nusantara Bertutur merupakan rubik koran Kompas yang terbit setiap hari Minggu. Selain diterbitkan dalam bentuk cetak, dongeng Nusantara Bertutur juga dapat dengan mudah diakses di Kompas online dan juga melalui media sosial facebook dan Instagram. Selaras dengan yang disampaikan oleh Putra (2019) bahwa "kemajuan teknologi justru memberikan wahana baru bagi pengembangan dongeng di Indonesia, baik sebagai warisan baru maupun dongeng-dongeng baru."

Secara garis besar, dongeng dalam Nusantara Bertutur memuat cerita pengalaman perjalanan seorang anak bersama keluarga mengunjungi sebuah destinasi wisata. Lebih detail lagi di dalamnya menceritakan banyak hal mulai dari perjalanan, mengisi liburan sekolah, berkunjung ke rumah nenek, meyaksikan tradisi upacara setempat dan masih banyak lagi. Dapat diketahui bahwa Nusantara Bertutur mencoba untuk menyajikan keberagaman pariwisata di Nusantara kepada anak-anak dengan kemasan dongeng. Hal ini tentu saja sangat menarik apabila dapat diuraikan dengan baik menggunakan pendekatan sastra pariwisata sebagai kajian pendukung teori sosiologi sastra dan strukturalisme.

Dipilihnya dongeng dalam Nusantara Bertutur yang bertema pariwisata sebagai fokus penelitian dilandasi beberapa alasan. Pertama, banyaknya dongeng bertema pariwisata sebagai salah satu bentuk eksplorasi penulis sastra anak dalam Nusantara Bertutur merupakan hal baru dan perlu diteliti untuk menguraikannya. Kedua, aspek pariwisata yang terdapat dalam Nusantara Bertutur bukan sekadar menyoroti permasalahan ekonomi melainkan sebagai pembelajaran bagi anakanak sehingga dapat berkontribusi dalam pembentukan karakter anak. Ketiga, tema pariwisata yang muncul dalam Nusantara Bertutur merupakan salah satu upaya promosi pariwisata di Indonesia agar dapat diketahui oleh masyarakat luas termasuk dalam hal ini adalah anak-anak.

Penelitian terhadap sastra anak telah banyak dilakukan, akan tetapi belum pernah menyentuh area perjalanan pariwisata. Kebanyakan penelitian terhadap sastra anak hanya berkutat seputar permasalahan pembentukan karakter dan nilai moral anak. Begitupula dengan penelitian sastra pariwisata sebagai sebuah pendekatan baru belum ada yang meneliti aspek pariwisata dalam sastra anak. Oleh karena itu untuk menguraikan aspek pariwisata yang terdapat dalam dongeng anak terkhusus Nusantara Bertutur Kompas 2019, penelitian ini sangat penting dilakukan. Dalam menganalisis aspek pariwisata dongeng yang terdapat di dalam Nusantara Bertutur Kompas tersebut, digunakan teori struktural, teori sosiologi sastra dengan pendekatan spesifik sastra pariwisata (literary tourism).

Nusantara Bertutur memuat dongeng modern dengan inovasi baru adanya audio dongeng. Setiap terbitnya terdapat barcode audio dongeng di halaman Nusantara Bertutur sehingga pembaca dapat memindai barcode dan menikmati audio dongeng yang telah disediakan. Hal tersebut tentu saja membuat anak-anak semakin mudah mengakses, menikmati sekaligus mengapresiasi karya sastra anak.

Nusantara Bertutur Kompas mempublikasikan satu dongeng tiap pekan. Dari minggu ke minggu, tema dongeng yang dimuat berbeda-beda. Dalam satu tahun, Kompas Minggu terbit antara 52 kali, kecuali ada libur nasional yang jatuh hari Minggu. Salah satu tema dominan yang diterbitkan sepanjang tahun 2019 adalah tema perjalanan pariwisata. Setidaknya terdapat 25 dongeng, dari total 49 dongeng yang dimuat, mengandung aspek kepariwisataan.

Jika dibuat dalam bentuk presentase, hampir 50\% dongeng dalam Nusantara Bertutur Kompas memberikan perhatian khusus terhadap pariwisata atau berlibur atau liburan. Hal tersebut menjadi dasar pemilihan tahun 2019 sebagai fokus penelitian. Dongeng bertema pariwisata dalam Nusantara Bertutur 
juga terdapat pada terbitan tahun 2020, akan tetapi jumlahnya hanya sedikit dan tidak menjadi tema dominan sebagaimana terbitan tahun 2019.

\section{KAJIAN SASTRA PARIWISATA DONGENG NUSANTARA}

Dongeng Nusantara Bertutur yang dimuat Kompas sepanjang tahun 2019 kaya akan tema cerita. Selain tema beragam, latar cerita dan pesan yang disampaikan pun beraneka. Membaca dongeng Nusangara Bertutur tidak akan menimbulkan kebosanan. Dibaca dengan pendekatan sastra pariwisata, dongeng-dongeng Nusantara Bertutur yang menjadi sampel penelitian ini dapat dikelompokkan menjadi lima, yaitu dongeng yang bertema (1) keindahan alam daya tarik wisata, (2) dongeng tentang kuliner nusantara, (3) perjalanan wisata, (4) dongeng yang menekankan interaksi antara wisatawan dan warga lokal, dan (5) dongeng yang melukiskan tentang tradisi, ritual budaya Nusantara. Karena tema atau subtema, ada juga cerita yang bisa dikelompokka ke dalam lebih dari satu kategori. Kelima aspek pariwisata tersebut saling berkaitan satu sama lain yang dapat membantu promosi pariwisata sekaligus sebagai sarana edukasi terhadap perkembangan anak melalui karya sastra khususnya dongeng anak.

\section{Keindahan Alam Daya Tarik Wisata}

Dongeng-dongeng yang bertema atau menarasikan keindahan alam daya tarik wisata sudah bisa diketahui dari judulnya. Nama daya tarik wisata itu sudah disebutkan dalam judul dongeng sehingga dongeng seperti ini bisa ditebak sebagai berusaha memperkenalkan tempat itu sebagai daya tarik wisata. Atau, bisa juga dibalik, bahwa dongeng berusaha untuk membuat dirinya menarik dengan memilih tempattempat terkenal sebagai judul sehingga memikat hati pembaca. Hal seperti ini bisa dilihat dalam dongengdongeng Liburan Ke Ranu Pani, Berwisata Ke Desa Wae Rebo, Wisata Ke Pulau Komodo, Desa Wisata Candirejo Borobudur, Berlibur Di Open Pit Nam Salu, dan Wisata Ke Geopark Belitung (Lihat Tabel 1). Sesuai judulnya, cerita pun menyajikan keindahan alam daya tarik wisata yang menjadi judul dongeng..

Tabel 1. Keindahan Alam Daya Tarik Wisata dalam Dongeng Nusantara Bertutur

\begin{tabular}{llll}
\hline No & $\begin{array}{c}\text { Judul } \\
\text { Dongeng }\end{array}$ & Pengarang & Daya Tarik Wisata \\
\hline \multirow{2}{*}{1} & Piknik ke & Jessica & Keindahan sunrise \\
& Negeri di & Valentina & Kong atas bukit King \\
& Awan & & Keindahan matahari \\
& Punthuk & Herdita Dwi & terbit di Punthuk \\
2 & Setumbu & R. & Setumbu \\
\hline
\end{tabular}

\begin{tabular}{|c|c|c|c|}
\hline 3 & $\begin{array}{l}\text { Liburan Ke } \\
\text { Ranu Pani }\end{array}$ & $\begin{array}{l}\text { Karunia } \\
\text { Sylviany } \\
\text { Sambas }\end{array}$ & $\begin{array}{l}\text { Pemandangan indah } \\
\text { di seputar Danau } \\
\text { Ranu Pani }\end{array}$ \\
\hline 4 & $\begin{array}{l}\text { Serunya } \\
\text { Karnaval } \\
\text { Sigale-Gale }\end{array}$ & $\begin{array}{l}\text { Lailatul } \\
\text { Badriyah }\end{array}$ & $\begin{array}{l}\text { Pemandangan danau } \\
\text { Toba }\end{array}$ \\
\hline 5 & $\begin{array}{l}\text { Rumah } \\
\text { Bung Karno } \\
\text { di Danau } \\
\text { Toba }\end{array}$ & $\begin{array}{l}\text { Dwi Ayu } \\
\text { Lestari }\end{array}$ & $\begin{array}{l}\text { Pemandangan } \\
\text { Danau Toba dari } \\
\text { atas rumah bung } \\
\text { Karno }\end{array}$ \\
\hline 6 & $\begin{array}{l}\text { Pantai Pink } \\
\text { Yang } \\
\text { Istimewa }\end{array}$ & Livia Halim & $\begin{array}{l}\text { Keindahan pasir } \\
\text { pink di pantai Pink }\end{array}$ \\
\hline 7 & $\begin{array}{l}\text { Pesona } \\
\text { Mandalika }\end{array}$ & $\begin{array}{l}\text { Deci } \\
\text { Rizkahayu } \\
\text { Lubis }\end{array}$ & $\begin{array}{l}\text { Pemandangan indah } \\
\text { di pantai Seger }\end{array}$ \\
\hline 8 & $\begin{array}{l}\text { Indahnya } \\
\text { Pantai } \\
\text { Mandalika }\end{array}$ & $\begin{array}{l}\text { Nurul } \\
\text { Ramadhanty }\end{array}$ & $\begin{array}{l}\text { Keunikan pasir dan } \\
\text { kejernihan air di } \\
\text { Pantai Mandalika }\end{array}$ \\
\hline 9 & $\begin{array}{l}\text { Festival Bau } \\
\text { Nyale Di } \\
\text { Mandalika }\end{array}$ & $\begin{array}{l}\text { Muthia } \\
\text { Razella }\end{array}$ & $\begin{array}{l}\text { Keindahan di pantai } \\
\text { Seger }\end{array}$ \\
\hline 10 & Batu Garuda & Acep Yonny & $\begin{array}{l}\text { Keindahan pantai } \\
\text { Tanjung Klayang }\end{array}$ \\
\hline 11 & $\begin{array}{l}\text { Wisata Ke } \\
\text { Geopark } \\
\text { Belitung }\end{array}$ & $\begin{array}{l}\text { Yudi } \\
\text { Suharso }\end{array}$ & $\begin{array}{l}\text { Pemandangan } \\
\text { pantai Tanjung } \\
\text { Tinggi }\end{array}$ \\
\hline 12 & $\begin{array}{l}\text { "Snorkeling } \\
\text { "Di Pulau } \\
\text { Kelor }\end{array}$ & $\begin{array}{l}\text { Ilda V } \\
\text { Siregar }\end{array}$ & $\begin{array}{l}\text { Keindahan alam } \\
\text { bawah laut Pantai } \\
\text { Pulau Kelor }\end{array}$ \\
\hline 13 & $\begin{array}{l}\text { Desa Wisata } \\
\text { Candirejo } \\
\text { Borobudur }\end{array}$ & $\begin{array}{l}\text { Hidayah } \\
\text { Nuril Pasha }\end{array}$ & $\begin{array}{l}\text { Pemandangan alam } \\
\text { pedesaan }\end{array}$ \\
\hline
\end{tabular}

Disimak dari temanya, ke-13 cerita tabel 1 bisa dipilah menjadi lima kelompok yaitu (a) keindahan alam pantai, (b) alam danau, (c) alam perdesaan, (d) matahari terbit, dan (e) keindahan alam bawah laut. Kelima keindahan alam yang terdapat dalam dongeng mendeskripsikan tempat wisata secara detail dengan cara disampaikan langsung oleh penulis, maupun dialog antar tokoh. Keindahan matahari terbit yang disajikan dalam dongeng terlihat di bukit King Kong dan di Punthuk Setumbu - Jawa Tengah.

Keindahan Danau Ranu Pani dan Danau Toba bisa dinarasikan dalam tiga dongeng masing-masing berjudul Liburan Ke Ranu Pani serta Danau Toba di Sumatera Utara dalam dongeng Serunya Karnaval Sigale-Gale dan Rumah Pengasingan Bung Karno di Danau Toba. Adapun Keindahan yang digambakan berupa pemandangan indah sekitar danau, suasana angin yang sejuk, dan kelestarian alamnya.

Keindahan pantai merupakan keindahan yang paling banyak muncul dalam dongeng. Tak heran, karena Indonesia merupakan negara kepulauan sehinggga memiliki banyak pantai. pantai yang terdapat dalam dongeng Nusantara Bertutur sepanjang 2019 adalah Pantai Pink, Pantai Seger, Pantai Mandalika, Pantai 
Tanjung Kelayang, dan Pantai Tanjung Tinggi. Masingmasing pantai mempunyai keunikan yang menjadi daya tarik yang kuat. Masing-masing pantai mempunyai keunikan yang menjadi daya tarik tersendiri bagi wisatawan untuk berkunjung. Keunikan tersebut berupa pasir pantai adanya ikon tertentu yang terdapat di kawasan pantai seperti monumen Putri Mandalika dan Batu Garuda.

Dongeng "Snorkeling” di Pulau Kelor merupakan satusatunya dongeng yang mendeskripsikan keindahan bawah laut. Dongeng tersebut menceritakan tentang pengalaman tokoh dan teman-temannya yang melakukan snorkeling (menyelam di permukaan untuk melihat keindahan karang dan ikan-ikan) di Pulau Kelor, daerah Labuan Bajo, kompleks kepulauan komodo. Keindahan yang diungkapkan berupa ikanikan warna-warni berada di sekitar mereka sehingga dapat menarik perhatian. Dongeng ini akan menjadi daya tarik untuk pembacanya untuk mencari tau lebih lanjut baik itu tentang kegiatan snorkeling maupun tentang keindahan dan ragam biota laut yang terdapat di Indonesia. Kutipan berikut melukiskan tokoh-tokoh berenang menyaksikan keindahan alam bawah air laut.

"Indina, Inaya, Rani dan Rini, kemudian melakukan snorkeling bersama. Sambil berenang santai, mereka menikmati keindahan pemandangan bawah laut di Pulau Kelor. Ikan-ikan cantik beraneka ragam warna berseliweran di sekitar, menarik perhatian mereka" (Siregar, 2019)

Dongeng Desa Wisata Candirejo Borobudur menggambarkan desa sebagai destinasi wisata desa budaya. Keindahan desa yang terdapat dalam dongeng berupa pemandangan aktivitas masyarakat sekitar, pemandagan alam serta budaya sekitar.

"Desa yang lokasinya sekitar 3 kilometer arah Tenggara Candi Borobudur ini berada di lokasi yang unik, yaitu di tengah padang rumput hijau dan hutan hujan tropis. Desa Wisata Candirejo terkenal dengan lingkungannya yang masih asri, karena selalu menjaga kelestarian alam. Selain itu, warga desa ini juga sangat menjaga kebudayaan setempat" (Phasa, 2019).

Dari cerita-cerita di atas bisa diketahui nama daerah wisata di Indonesia dan keindahan yang dimiliki, ditawarkan, kepada wisatawan. Sebagai cerita atau dongeng pendek, tentu saja uraian tidak sedetil buku panduan wisata. Meskipun demikian, pesan intik memperkenalkan keindahan daya tarik wisata sudah eksplisit tetapi tetapi jauh dari kesan propoganda.

\section{Pengenalan Kuliner Nusantara}

Indonesia dikenal sebagai salah satu surga kuliner dengan berbagai cita rasa. Tak jarang kuliner terdapat dalam sebuah karya sastra, termasuk sastra anak. Sastra kuliner dapat dijadikan sebagai media dalam memperkenalkan sekaligus melestarikan kuliner Nusantara.

Hartini (2009) mendefinisikan kuliner sebagai wujud pencapaian estetika tentang bagaimana bangsa dalam rentang waktu sejarah tertentu terbangun dengan spirit dan cita rasa. Kegiatan wisata berkait erat dengan penikmatan kuliner di tempat tujuan wisata. Wisatawan yang berkunjung ke Bali tentau berkeinginan mencoba ayam betutu, yang berlibur ke Palembang akan mencoba empek-empek di daerah tersebut.

Selain sebagai pelengkap dalam perjalanan wisatawan, kuliner juga sering menjadi ciri khas sebuah daerah untuk mengangkat identitas kolektif. Endraswara mengemukakan "makanan yang digarap dalam karya sastra sebenarnya merujuk pada identitas suatu kolektif. Makanan sebagai polesan sastra tentu bukan milik individual, melainkan sebuah cetusan kolektif" (2018: 41).

Dongeng Nusantara Bertutur yang mengangkat tema kuliner cukup banyak (Tabel 2). Trend ini diperkirakan terus meningkat karena kekayaan kuliner Nusantara memang menarik untuk diperkenalkan. Hadirnya banyak gerai makanan Barat seperti McDonal, Pizza, dan KFC yang relatif mahal, mendorong masyarakat untuk mengangkat kekhasan kuliner lokal yang relatif murah. Yang lebih penting dari itu adalah gastronomi lokal bermanfaat dalam menguatkan identitas Nusantara.

Tabel 2. Kuliner Nusantara dalam Dongeng Nusantara Bertutur

\begin{tabular}{llll}
\hline No & \multicolumn{1}{c}{$\begin{array}{c}\text { Judul } \\
\text { Dongeng }\end{array}$} & Pengarang & \multicolumn{1}{c}{$\begin{array}{c}\text { Kuliner } \\
\text { Nusantara }\end{array}$} \\
\hline 1 & $\begin{array}{l}\text { Erika dan } \\
\text { Tradisi Hari } \\
\text { Raya Karo } \\
\text { Berwisata }\end{array}$ & $\begin{array}{l}\text { Laksmi } \\
\text { Manohara }\end{array}$ & Kentang Krawu \\
2 & $\begin{array}{l}\text { Ke Desa } \\
\text { Wae Rebo } \\
\text { Serunya }\end{array}$ & Yuli Susanthi & $\begin{array}{l}\text { Sei, Rumpu } \\
\text { Rampe, Kolo }\end{array}$ \\
& $\begin{array}{l}\text { Barter Di } \\
\text { Pasar }\end{array}$ & Lintang & Kinanti \\
& Warloka & Deci & \\
4 & $\begin{array}{l}\text { Pesona } \\
\text { Mandalika }\end{array}$ & $\begin{array}{l}\text { Rizkahayu } \\
\text { Lubis }\end{array}$ & Ayam Taliwang \\
5 & Dusun Sade & Siti Nurlaela & $\begin{array}{c}\text { Ayam Taliwang } \\
\text { Plecing Kangkung }\end{array}$ \\
\hline
\end{tabular}




\begin{tabular}{|c|c|c|c|}
\hline 6 & $\begin{array}{l}\text { Festival Bau } \\
\text { Nyale di } \\
\text { Mandalika }\end{array}$ & $\begin{array}{l}\text { Muthia } \\
\text { Razella }\end{array}$ & $\begin{array}{l}\text { Pata'u Ni } \\
\text { Sambal Nyale } \\
\text { Pa'dongo }\end{array}$ \\
\hline 7 & $\begin{array}{l}\text { Tangis } \\
\text { Keramba } \\
\text { Opung }\end{array}$ & $\begin{array}{l}\text { Geti Oktaria } \\
\text { Pulungan }\end{array}$ & Masakan Arsik \\
\hline 8 & $\begin{array}{l}\text { Menjaga } \\
\text { Kelestarian } \\
\text { Danau Toba }\end{array}$ & $\begin{array}{l}\text { Lailatul } \\
\text { Badriyah }\end{array}$ & $\begin{array}{l}\text { Masakan Arsik } \\
\text { Sirup Markisa }\end{array}$ \\
\hline 9 & $\begin{array}{l}\text { Serunya } \\
\text { Karnaval } \\
\text { Sigale-Gale }\end{array}$ & $\begin{array}{l}\text { Lailatul } \\
\text { Badriyah }\end{array}$ & $\begin{array}{l}\text { Ikan Mas Arsik } \\
\text { Denge Mas Na } \\
\text { Niura } \\
\text { Daun Ubi Tumbuk }\end{array}$ \\
\hline 10 & $\begin{array}{l}\text { Punthuk } \\
\text { Setumbu }\end{array}$ & $\begin{array}{l}\text { Herdita Dwi } \\
\text { R. }\end{array}$ & Gethuk Magelang \\
\hline 11 & Batu Garuda & Acep Yonny & Kopi \\
\hline
\end{tabular}

Dongeng Berwisata ke Desa Wae Rebo mencantumkan kuliner yang dituturkan langsung oleh penulis dalam kutipan narasi berikut.

"Hari beranjak malam, Lintang dan teman-teman menikmati makanan yang disuguhkan oleh istri Pak Sapri. Ada se'i makanan khas Labuan Bajo yang terbuat dari daging sapi asap, rumpu rampe atau tumisan aneka macam jenis sayur, ikan bakar segar lengkap dengan sambalnya, kolo nasi bakar khas Labuan Bajo, serta teh hangat beraroma gula aren asli Nusa Tenggara. Sungguh nikmat semuanya." (Susanthi, 2019).

Kutipan di atas menggambarkan kekayaan kuliner masyarakat Desa Wae Rebo. Makanan pertama adalah Se'i makanan khas Labuan Bajo yang terbuat dari daging sapi asap. Kuliner kedua berupa ruтри rampe atau tumisan aneka macam jenis sayur. Selanjutnya terdapat ikan bakar segar lengkap dengan sambalnya. Terakhir kuliner yang tercantum dalam dongeng adalah kolo nasi bakar khas Labuan Bajo. Sedangkan untuk minumannya teh hangat beraroma gula aren asli Nusa Tenggara. Dongeng tak hanya mempromosikan Wae Rebo sebagai daya tarik wisata tetapi juga memperkenalkan makanan lokal sebagai salah satu kekayaan Nusantara.

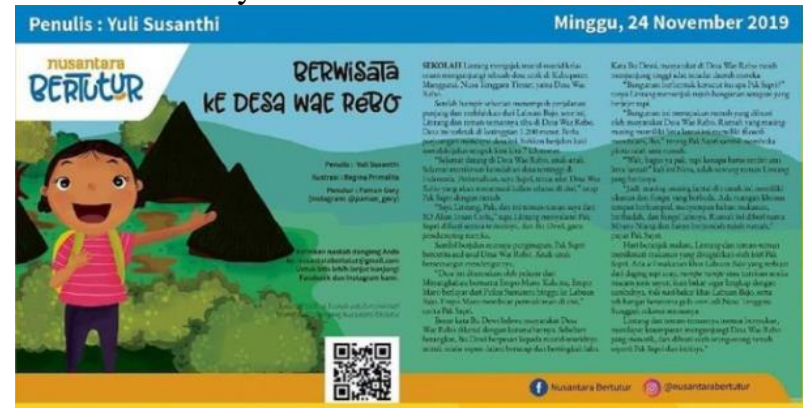

Gambar 1. Dongeng Berwisata ke Desa Wae Rebo (Kompas, 2019).
Di samping itu, dongeng Nusantara Bertutur memuat beberapa kuliner di enam daerah. Dongeng Erika dan Tradisi Hari Raya Karo mencantumkan kentang krawu sebagai makanan khas Bromo Jawa Timur ketika Hari Raya Karo berlangsung. Makanan tradisional daerah Labuan Bajo yang tercantum dalam dua dongeng adalah Sei, Rumpu Rampe, Kolo, dan Lawar Pansa. Makananmakanan tersebut dihidangkan oleh warga lokal ketika tokoh berkunjung ke desa Wae Rebo.

Daerah Lombok memiliki kuliner khas yakni ayam taliwang, plecing kangkung, pata'u ni dan sambal nyale pa'dongo. Kuliner-kuliner tersebut tercatum dalam 3 dongeng bertema wisata Lombok. Tiga dongeng bertema Danau Toba mencantumkan kuliner khas berupa sirup markisa, ikan mas arsik denge mas na niura, dan daun ubi tumbuk. Kuliner khas Magelang berupa gethuk terdapat pada dongeng Punthuk Setumbu. Sedangkan pada dongeng Batu Garuda terdapat kuliner khas Belitung yakni kopi.

\section{Perjalanan Wisata}

Dongeng Nusantara Bertutur juga mengisahkan aktivitas perjalan menuju lokasi wisata dengan berbagai sarana transportasi dan aktivitas dalam perjalanan wisata itu. Perjalanan pariwisata dapat dibedakan berdasarkan alat transportasinya menjadi tiga yakni perjalanan darat, perjalanan laut, dan perjalanan udara. Lukisan perjalanan dalam dongeng Nusantara Bertutur bisa dilihat daftarnya dalam Tabel 3 .

Tabel 3. Perjalanan Wisata dalam Dongeng Nusantara Bertutur

\begin{tabular}{|c|c|c|c|}
\hline No & $\begin{array}{l}\text { Judul } \\
\text { Dongeng }\end{array}$ & Pengarang & $\begin{array}{l}\text { Perjalanan } \\
\text { Pariwisata }\end{array}$ \\
\hline 1 & $\begin{array}{l}\text { Liburan } \\
\text { Ke Ranu } \\
\text { Pani }\end{array}$ & $\begin{array}{l}\text { Karunia } \\
\text { Sylviany } \\
\text { Sambas }\end{array}$ & Darat; Mobil \\
\hline 2 & $\begin{array}{l}\text { Piknik ke } \\
\text { Negeri di } \\
\text { Awan }\end{array}$ & $\begin{array}{l}\text { Jessica } \\
\text { Valentina }\end{array}$ & $\begin{array}{l}\text { Darat dan Udara; } \\
\text { Mobil Jeep dan } \\
\text { Pesawat }\end{array}$ \\
\hline 3 & $\begin{array}{l}\text { Serunya } \\
\text { Barter di } \\
\text { Pasar } \\
\text { Warloka }\end{array}$ & $\begin{array}{l}\text { Lintang } \\
\text { Kinanti }\end{array}$ & Laut; Perahu Motor \\
\hline 4 & $\begin{array}{l}\text { Wisata ke } \\
\text { Pulau } \\
\text { Komodo }\end{array}$ & Yeni Endah & Laut; Speed Boat \\
\hline 5 & $\begin{array}{l}\text { "Snorkelin } \\
\text { g" di } \\
\text { Pulau } \\
\text { Kelor }\end{array}$ & $\begin{array}{l}\text { Ilda V } \\
\text { Siregar }\end{array}$ & Laut; Kapal Nelayan \\
\hline 6 & $\begin{array}{l}\text { Rumah } \\
\text { Bung } \\
\text { Karno di } \\
\text { Danau } \\
\text { Toba }\end{array}$ & $\begin{array}{l}\text { Dwi Ayu } \\
\text { Lestari }\end{array}$ & $\begin{array}{l}\text { Darat dan Udara; } \\
\text { Mobil dan Pesawat }\end{array}$ \\
\hline 7 & $\begin{array}{l}\text { Punthuk } \\
\text { Setumbu }\end{array}$ & $\begin{array}{l}\text { Herdita } \\
\text { Dwi R. }\end{array}$ & Darat; Mobil \\
\hline
\end{tabular}




\begin{tabular}{clll}
\hline 8 & $\begin{array}{l}\text { Dinding- } \\
\text { Dinding } \\
\text { Bercerita } \\
\text { Jalan- }\end{array}$ & Elisa DS & Darat; Mobil \\
& Jalan Ke & Lailatul & \\
9 & $\begin{array}{l}\text { Pulau } \\
\text { Lengkuas }\end{array}$ & Badriyah & Laut; Perahu Motor \\
& Belitung & & \\
10 & $\begin{array}{l}\text { Batu } \\
\text { Garuda }\end{array}$ & Acep & Yonny \\
& $\begin{array}{l}\text { Wisata Ke } \\
\text { Geopark }\end{array}$ & Yudi & Udara; Pesawat \\
& Belitung & Suharso & \\
\hline
\end{tabular}

Dongeng "Snorkeling” di Pulau Kelor mencantumkan transportasi laut pada kutipan berikut.

"Pagi itu, rombongan mereka telah tiba di Pulau Kelor, yang ditempuh hanya sekitar setengah jam dari kota Labuan Bajo dengan menggunakan kapal nelayan.” (Siregar, 2019).

Penggalan dongeng di atas menjelaskan alat transportasi kapal nelayan sebagai sarana tokoh menuju lokasi wisata. Adapun dari kota Labuan Bajo menuju Pulau Kelor dapat ditempuh dengan durasi selama 30 menit.

Perjalanan dalam dongeng dibedakan berdasarkan alat transportasi yang digunakan wisatawan untuk menempuh perjalanan menuju lokasi wisata. Adapun (1) perjalanan darat dengan menggunakan mobil, (2) perjalanan laut dengan menggunakan perahu nelayan, perahu motor, speed boat, hingga kapal, (3) perjalanan udara menggunakan moda transportasi berupa pesawat.

Tokoh-tokoh dalam dongeng menggunakan berbagai alat transportasi selama melakukan perjalanan wisatanya. Alat transportasi yang digunakan oleh tokoh menggambarkan pula gaya hidup sekaligus latar belakang tokoh. Perjalanan tokoh cerita dengan menggunakan mobil dan pesawat menunjukkan bahwa mereka berasal dari kota dan kelas menengah ke atas. Hal ini menjadi bukti perkembangan dongeng modern saat ini begitu dinamis.

Berbeda halnya dengan dongeng tradisional yang biasanya berlatar sosial kemiskinan di daerah pedesaan. Berwisata lintas daerah dengan alat transportasi modern dalam dongeng Nusantara Bertutur mencerminkan kisah ini adalah tentang orang yang mampu, sesuatu yang berbeda dengan dongeng konvensional yang biasanya perjalanan dilukiskan dengan berjalan kaki. Tema wisata merupakan sesuatu yang tidak lazim dalam dongeng lama. Pariwisata merupakan gaya hidup masyarakat modern.

\section{Interaksi Wisatawan dan Penduduk Lokal}

Dalam kegiatan wisata, interaksi antara wisatawan dan penduduk lokal adalah keniscayaan. Dalam ilmu antropologi pariwisata, interaksi itu disebut interaksi antara guest (tamu/ turis) dan host (tuan rumah) (Smith, 1989). Dalam bentuk yang paling nyata, kontak itu bisa terjadi antara wisatawan dengan karyawan hotel, restoran, supir, pemandu wisata, penjaga tiket di data tarik wisata, atau dengan masyarakat umum di tempattempat yang memungkinan. Manusia adalah makhluk sosial, kontak dengan orang lain adalah keniscayaan (Sudariyanto, 2019: 21), tentu saja ini berlaku juga untuk kontak termasuk antara wisatawan dan tuan rumah.

Dalam karya sastra, interaksi juga terjadi antar tokoh satu dengan tokoh yang lain baik saling berdialog maupun bekerja sama. Interaksi dapat dengan mudah ditemukan hampir di seluruh karya sastra. Seperti halnya dalam dongeng Nusantara Bertutur Kompas. Secara garis besarnya terdapat dua jenis interaksi yakni interaksi wisatawan dengan pemandu wisata dan interaksi wisatwan dengan masyarakat lokal (Tabel 4).

Tabel 4. Interaksi Wisatawan dan Penduduk Lokal dalam Dongeng Nusantara Bertutur

\begin{tabular}{|c|c|c|c|}
\hline No. & $\begin{array}{l}\text { Judul } \\
\text { Dongeng }\end{array}$ & Pengarang & Bentuk Interaksi \\
\hline 1 & $\begin{array}{l}\text { Memotret } \\
\text { Upacara } \\
\text { Kasada }\end{array}$ & $\begin{array}{l}\text { Anisah } \\
\text { Sholichah }\end{array}$ & $\begin{array}{l}\text { Menginap di } \\
\text { rumah pak Lingga } \\
\text { sebagai warga } \\
\text { lokal }\end{array}$ \\
\hline 2 & $\begin{array}{l}\text { Naik Kuda ke } \\
\text { Kawah Bromo }\end{array}$ & Cempaka & $\begin{array}{l}\text { Berbincang } \\
\text { dengan } \\
\text { penggembala } \\
\text { kuda lokal }\end{array}$ \\
\hline 3 & $\begin{array}{l}\text { Piknik ke } \\
\text { Negeri di } \\
\text { Awan }\end{array}$ & $\begin{array}{l}\text { Jessica } \\
\text { Valentina }\end{array}$ & $\begin{array}{l}\text { Diantar oleh } \\
\text { pemandu wisata }\end{array}$ \\
\hline 4 & $\begin{array}{l}\text { Berwisata ke } \\
\text { Desa Wae } \\
\text { Rebo }\end{array}$ & $\begin{array}{l}\text { Yuli } \\
\text { Susanthi }\end{array}$ & $\begin{array}{l}\text { Disambut, diantar } \\
\text { dan dijelaskan } \\
\text { oleh kepala adat } \\
\text { desa }\end{array}$ \\
\hline 5 & $\begin{array}{l}\text { Serunya } \\
\text { Barter di } \\
\text { Pasar Warloka }\end{array}$ & $\begin{array}{l}\text { Lintang } \\
\text { Kinanti }\end{array}$ & $\begin{array}{l}\text { Interaksi penjual } \\
\text { cumi dan Nadine }\end{array}$ \\
\hline 6 & $\begin{array}{l}\text { Wisata ke } \\
\text { Pulau } \\
\text { Komodo }\end{array}$ & Yeni Endah & $\begin{array}{l}\text { Bersama } \\
\text { wisatawan } \\
\text { didampingi oleh } \\
\text { pemandu wisata }\end{array}$ \\
\hline 7 & Dusun Sade & $\begin{array}{l}\text { Siti } \\
\text { Nurlaela }\end{array}$ & $\begin{array}{l}\text { Wisatawan } \\
\text { berkunjung ke } \\
\text { desa }\end{array}$ \\
\hline 8 & $\begin{array}{l}\text { Indahnya } \\
\text { Pantai } \\
\text { Mandalika }\end{array}$ & $\begin{array}{l}\text { Nurul } \\
\text { Ramadhant } \\
\text { y }\end{array}$ & $\begin{array}{l}\text { Ditemani oleh } \\
\text { pemandu wisata }\end{array}$ \\
\hline 9 & $\begin{array}{l}\text { Desa Wisata } \\
\text { Candirejo } \\
\text { Borobudur }\end{array}$ & $\begin{array}{l}\text { Hidayah } \\
\text { Nuril Pasha }\end{array}$ & $\begin{array}{l}\text { Paman Dion } \\
\text { sebagai pemandu } \\
\text { wisata lokal }\end{array}$ \\
\hline
\end{tabular}




\begin{tabular}{clll}
\hline 10 & $\begin{array}{l}\text { Berlibur di } \\
\text { Open Pit Nam } \\
\text { Salu }\end{array}$ & $\begin{array}{l}\text { Yudi } \\
\text { Suharso }\end{array}$ & $\begin{array}{l}\text { Ditemani oleh } \\
\text { pemandu wisata } \\
\text { setempat }\end{array}$ \\
Salan-Jalan ke & Acep & $\begin{array}{l}\text { Ditemani oleh } \\
\text { pemandu wisata } \\
\text { setempat }\end{array}$ \\
& $\begin{array}{l}\text { Lulau } \\
\text { Bengkuas }\end{array}$ & Yonny & $\begin{array}{l}\text { Ditemani oleh } \\
\text { pemandu wisata } \\
\text { lokal }\end{array}$ \\
\hline
\end{tabular}

Terdapat empat dongeng yang menunjukkan interaksi dengan warga lokal yakni masing-masing terdapat pada dongeng Memotret Upacara Kasada, Naik Kuda ke Kawah Bromo, Berwisata ke Desa Wae Rebo, dan Serunya Barter di Pasar Warloka.

Dongeng Serunya Barter Di Pasar Warloka menujukkan adanya interaksi antara Nadine (wisatawan) dengan pedangang cumi-cumi di pasar tradisional Warloka. Interaksi jual beli yang terjadi sangatlah unik karena masih menggunakan sistem barter. Dapat diketahui dari penggalan berikut.

"Nadine bertanya pada pedagang cumi-cumi, apakah ia boleh menukar cumi-cumi dengan beras yang dibawanya. Pedagang itu menyetujuinya"

(Kinanti, 2019).

Kutipan di atas menunjukkan interaksi Nadine dengan pedagang lokal saat melakukan barter cumi-cumi dengan beras yang dibawanya. Interaksi itu berlangsung dalam suasana harmonis dan tujuan pihak yang berinteraksi pun tercapai.

Interaksi dengan warga lokal pada dongeng Nusantara Bertutur terjadi dalam berbagai konteks dengan latar belakang host berbeda-beda. Misalnya, antara guest dengan penjaga usaha akomodasi yang menyediakan penginapan, pegawai yang menyambut dengan ramah, menyuguhkan makanan, berbincang-bincang hingga melakukan transaksi jual beli. Interaksi ini menunjukkan kepada anak-anak sebagai wisatawan bahwa mereka dapat berinteraksi dengan warga lokal sangat mengasyikkan. Selain itu, interaksi anak-anak mengetahui interaksi apa saja yang akan terjadi ketika berwisata.

\section{Tradisi dan Budaya dalam Dongeng Nusantara}

Indonesia memiliki beraneka ragam tempat wisata yang masing-masing memiliki ciri khas tersendiri. Tiap-tiap daerah berupaya mengenalkan dan mempopulerkan potensi wisata yang ada. Tim Edukasi, (2020:6) menambahkan "selain untuk menambah pendapatan daerah, wisata ini salah satu cara untuk tetap melestarikan budaya bangsa dan mengenalkan suatu daerah tertentu."

Beberapa budaya yang ikut mewarnai dongeng adalah (1) Upacara Kasada dan (2) Hari Raya Karo suku Tengger keduanya di Bromo, Jawa Timur, (3) karnaval Sigale-gale di Danau Toba, serta (4) Jathilan di Magelang Jawa Tengah (Tabel 5).

Tabel 5. Tradisi dan Budaya dalam Dongeng Nusantara Bertutur

\begin{tabular}{|c|c|c|c|}
\hline No. & $\begin{array}{c}\text { Judul } \\
\text { Dongeng }\end{array}$ & Pengarang & $\begin{array}{c}\text { Tradisi dan } \\
\text { Budaya }\end{array}$ \\
\hline 1 & $\begin{array}{l}\text { Memotret } \\
\text { Upacara } \\
\text { Kasada }\end{array}$ & $\begin{array}{l}\text { Anisah } \\
\text { Sholichah }\end{array}$ & 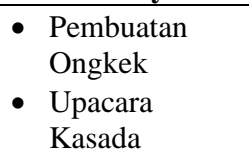 \\
\hline 2 & $\begin{array}{l}\text { Erika dan } \\
\text { Tradisi Hari } \\
\text { Raya Karo }\end{array}$ & $\begin{array}{l}\text { Laksmi } \\
\text { Manohara }\end{array}$ & $\begin{array}{l}\text { - Hari Raya Karo } \\
\text { - Tradisi } \\
\text { Sadranan } \\
\text { - Festival Bau }\end{array}$ \\
\hline 3 & $\begin{array}{l}\text { Festival } \\
\text { Bau Nyale } \\
\text { di } \\
\text { Mandalika }\end{array}$ & $\begin{array}{l}\text { Muthia } \\
\text { Razella }\end{array}$ & $\begin{array}{l}\text { Nyale } \\
\text { - Kesenian } \\
\text { Tradisional } \\
\text { (betandak, } \\
\text { bejambik, } \\
\text { belancaran) }\end{array}$ \\
\hline 4 & $\begin{array}{l}\text { Serunya } \\
\text { Karnaval } \\
\text { Sigale-Gale }\end{array}$ & $\begin{array}{l}\text { Lailatul } \\
\text { Badriyah }\end{array}$ & $\begin{array}{ll}\text { - Kernaval } \\
\text { Sigale-Gale } \\
\text { - Tari Tor-tor } \\
\text { - Musik } \\
\text { - Gondang } \\
\text { - Parade ulos }\end{array}$ \\
\hline 5 & $\begin{array}{l}\text { Desa } \\
\text { Wisata } \\
\text { Candirejo } \\
\text { Borobudur }\end{array}$ & $\begin{array}{l}\text { Hidayah Nuril } \\
\text { Pasha }\end{array}$ & $\begin{array}{l}\text { - Manoreh } \\
\text { - Tari Jathilan }\end{array}$ \\
\hline
\end{tabular}

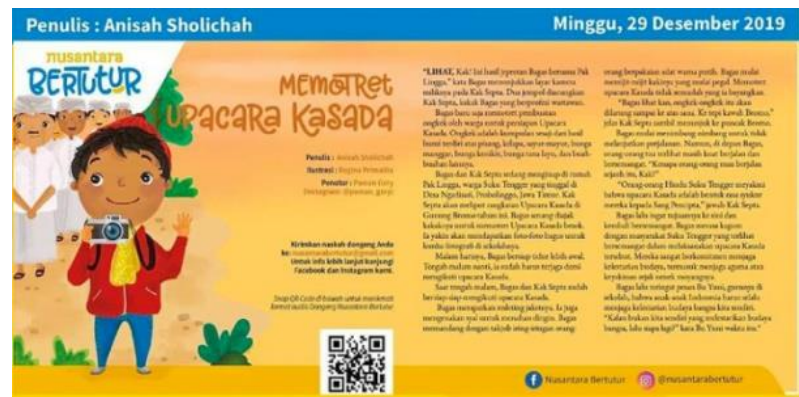

Gambar 2. Dongeng Memotret Upacara Kasada (Kompas, 2019).

Dongeng Memotret Upacara Kasada menceritakan tentang pemotretan perayaan upacara Kasada oleh tokoh Bagas. Beberapa ritual adat dalam upacara dipaparkan dalam dongeng pada kutipan berikut:

"Bagas baru saja memotret pembuatan ongkek oleh warga untuk persiapan upacara Kasada. Ongkek 
adalah kumpulan sesaji dari hasil bumi terdiri atas pisang, kelapa, sayur-mayur, bunga manggar, bunga kenikir, bunga tana layu, dan buah-buahan lainnya" (Sholichah, 2019).

Kutipan di atas menceritakan tentang pembuatan ongkek sebagai sesaji yang akan dilemparkan ke kawah Gnung Bromo. Sesaji tersebut terbuat dari hasil bumi masyarakat setempat yang dibuat oleh tetua adat. Ongkek biasanya berisi sayur-mayur diantaranya ada kentang, kubis, kacang-kacangan, daun pakis, pare, buah pisang dan sebagainya. Pembuatan ongkek itulah yang diabadikan oleh tokoh Bagas dalam fotonya. Tema pembuatan dan penjelasan keguanan ongkek ini sebetulnya wujud kuliner (sesaji) namun tidak dimasukkan ke dalam kategori tematik kuliner karena ongkek merupakan sesaji untuk Tuhan.

Dongeng Nusantara Bertutur dapat menyuguhkan paket lengkap dalam satu dongeng sekaligus. Di samping eksplorasi pariwisata, budaya juga menjadi fokus penting dalam dongeng. Keragaman budaya Indonesia perlu terus dijaga sepenuh hati dari generasi ke generasi. Dongeng Nusantara Bertutur menjadi wujud langkah konkrit melestarikan kekayaan budaya Indonesia melalui sastra anak.

Pada akhirnya dapat diketahui bahwa sastra dan pariwisata bertautan sedemikian erat. Bersinergi membangun literasi, edukasi dan promosi pariwisata dalam waktu yang bersamaan. Nyatanya, dongeng anak yang selama ini belum mendapatkan sentuhan spesial dari para peneliti begitu memukau. Masih banyak nilai yang dapat digali, diselami lalu disuguhkan dengan demikian menggairahkan. Dengan demikian, dongeng tidak saja berisi nasehat moral (Karmini, 2020), tidak saja mengandung kisah dan identitas etnik (Suardika dan Hafid, 2021), tidak saja berkaitan dengan gastronomi (Laksmita Sari, Putra, dan Giri, 2020), tidak saja sebagai bagian tradisi lisan yang menjadi sumber inspirasi untuk menulis sastra modern seperti novel (Putra 2011; Harini 2012), tetapi juga mengandung berbagai wujud promosi pariwisata (Harini, 2018).

\section{SIMPULAN}

Berdasarkan pembahasan di atas dapat disimpulkan bahwa dongeng dan tradisi mendongeng yang pernah dikhawatirkan akan lenyap ternyata berkembang terus dalam wujud yang baru. Secara konvensional, dongeng merupakan cerita komunal yang tidak ada pengarangnya, dalam dongeng baru yang dalam tulisan ini disebutkan 'dongeng modern', tampil dengan nama penulis, dimuat di surat kabar, dan beredar lintas daerah. Pada masa lalu, dongeng kebanyakan beredar secara lisan biasanya di wilayah terbatas perdesaan. Jika ada dongeng beredar ke luar desa, niscaya dongeng itu akan hadir dengan variasi-variasinya. Dongen modern hadir secara tetap dan di mana pun dibaca isi cerita tetap demikian seperti tertulis.

Dalam analisis juga disinggung kehadiran tradisi mendongeng dari di rumah sebagai ruang tertutup, meluar ke ruang terbuka seperti pertokoan, dan kemudian ruang digital seperti kanal Youtube. Dengan kemajuan teknologi digital, tradisi mendongeng hadir dalam bentuk baru yang pada akhirnya juga memperkuat kehidupan dongeng dan tradisi mendongeng, walau berbagai perubahan terjadi menyesuaikan dengan perkembangan iptek.

Analisis tematik, latar, dan tokoh atas dongeng Nusantara Bertutur yang dimuat di harian Kompas 2019 menunjukkan kecenderung kuat ke arah promosi pariwisata. Hal ini terliaht dalam kisah-kisah cerita yang memperkenalkan destinasi wisata seperti Labuan Bajo, Wae Rebo, Candirejo. Kecenderungan ini sejalan dengan komitman masyarakat dan pemerintah dalam mengembangkan pariwisata Indonesia sebagai sumber pekerjaan, pendapatan pajak lokal, dan devisa negara.

Dalam memperkenalkan daya tarik atau destinasi wisata itu, para penulis dongeng memberikan penekanan yang berbeda pada keindahan alam, keunikan kuliner, keindahan alam bawah laut, dan hubungan antara tamu dan tuan rumah. Dengan mengungkapkan aspek-aspek promosi wisata tersebut memungkinkan untuk mengatakan bahwa dongeng modern Nusantara Bertutur bukan saja sebagai pelipur lara, hiburan semata, tetapi juga padat akan substansi promosi pariwisata Nusantara.

Penelitian ini hanya terfokus pada analisis karya sastra, maka dari itu penelitian sejenis masih dapat dikembangkan dengan melakukan penelitian lebih lanjut pada penulis maupun pembacanya. Diharapkan ada penelitian yang dapat menyempurnakan penelitian serupa untuk menambah referensi dalam bidang kritik sastra terkhusus pada sastra anak dan kajian sastra pariwisata.

\section{DAFTAR PUSTAKA}

Anoegrahjekti, Novi, Djoko Sarjono, dan I Nyoman Darma Putra (ed.). (2020). Sastra Pariwisata. Yogyakarta: PT Kanisius.

Ardi, Monicha. (2013). Kecenderungan Tematis Cerpen Anak dalam Harian Kompas Edisi Januari-Maret 2012: 
Kajian Sosiologi Sastra. Program Studi Sastra Indonesia FBS Universitas Negeri Padang.

Artawan, Gde. (2020). Aku Cinta Lovina: Peran Sastra dalam Mempromosikan Pariwisata Bali Utara. Jurnal Master Pariwisata (JUMPA), , 241-256. doi:10.24843/JUMPA.2020.v07.i01.p11.

Aryani, Made Ratna Dian. (2021). Struktur dan Sifat Pelesapan dalam Cerita Rakyat Bali. Jurnal Kajian Bali (Journal Of Bali Studies), 11(1), 97-114. doi:10.24843/JKB.2021.v11.i01.p06

Basuki, Sunaryono. (2017). Aku Cinta Lovina. denpasar: Pustaka Larasan.

Endraswara, Suwardi. (2018). Metodologi Gastronomi Sastra. Yogyakarta: Textium.

Endriani, Deni. 2015. "Making a Tourism Icon: The valorization of Siti nurbaya bridge in West Sumatera", JUMPA 1 [2] : $43-56$.

Harini, Yostiani Noor Asmi. (2012). "Transformasi Folklor Lisan Nini Anteh Ke Novel Dongeng Nini Anteh Karya A.S. Kesuma”, Jurnal Pendidikan Bahasa dan Sastra, Volume 12, Nomor 2, Oktober 2012.

Harini, Yostiani Noor Asmi. (2018). "The Use of Legend in Tourism: Case Study of Si Pitung from Indonesia." dalam Advances in Social Science, Education and Humanities Research, volume 231, 5th International Conference on Community Development (AMCA 2018) : 445-447.

Hartini, S. (2009). Wisata Kuliner Indonesia. Yogyakarta: Tugu.

Jefrika, Reza. (2020). Gambaran Pariwisata di Kota Padang dalam Novel Sitti Nurbaya Karya Marah Rusli dan Pengaruh Novel Sitti Nurbaya Terhadap Perkembangan Pariwisata Kota Padang Masa Kini. Program Studi Sastra Indonesia Universitas Andalas.

Karmini, N. N. (2020). Pendidikan Karakter Dalam Cerita Rakyat Rajapala. Mudra Jurnal Seni Budaya, 35(1), 22-29.

https://doi.org/10.31091/mudra.v35i1.994

Kompas.com.

(2008).

"Makam.Siti.Nurbaya.Sepi.Pengunjung" Link: http://nasional.kompas.com/read/2008/10/19/1623197

3/Makam. Siti.Nurbaya.Sepi.Pengunjung Diakses 28/11/2017.
Laksmita Sari, I. (2019). Unsur-unsur Pengetahuan Sosial dalam Cerita Rakyat Bali Aga dan Buku Pelajaran Sekolah Dasar Zaman Kolonial Belanda. Jurnal Kajian Bali (Journal Of Bali Studies), 9(2), 499520. doi:10.24843/JKB.2019.v09.i02.p11

Laksmita Sari, I. A. (2019). Antara Teks dan Praktik: Ritual Iomante pada Cerita Rakyat Ainu Jepang. Mudra Jurnal Seni Budaya, 34(2), 205-212. https://doi.org/10.31091/mudra.v34i2.702.

Laksmita Sari, Ida Ayu dan I Nyoman Darma Putra. (2020). "Narrative on Nature Conservation: A Comparative Study of the Folktales of Bali Aga and Ainu", KEMANUSIAAN The Asian Journal of Humanities, 27 (2), pp. 59-78.

Laksmita Sari, Ida Ayu I Nyoman Darma Putra, Ni Luh Kade Yuliani Giri. (2020). "Gastronomi dalam Cerita Rakyat Ainu Jepang”, Jurnal Panggung, Vol. 30, No. 2, pp. 235-250.

Liputan6.com. (2017). "Wajah Baru Pariwisata Belitung Pasca-Novel Laskar Pelangi", Link http://lifestyle.liputan6.com/ read/3090004/wajahbaru-pariwisata-belitung-pasca-novellaskar-pelangi Diakses: 28/11/2017

Melton, Jeffrey Alan. (2002). Mark Twain, Travel Books, and Tourism. Alabama: The University of Alabama Press.

Narulita, Sari. (2016). Cintaku di Lembata. jakarta: Gramedia Pustaka Utama.

Putra, I Nyoman Darma. (2011). "Novel 'Tantri', Daur Ulang Nilai-nilai untuk Pembentukan Karakter Bangsa", Jurnal Kajian Bali (Journal Of Bali Studies), 2(1). Retrieved from https://ojs.unud.ac.id/index.php/kajianbali/article/view/ 15651

Putra, I Nyoman Darma. 2017. "Literary Tourism: Kajian Sastra Dengan Pendekatan Pariwisata", Makalah: Disampaikan dalam Seminar Nasional pada Prodi Bahasa Inggris - FIB, Universitas Diponogoro, Semarang, 30/11/2017.

Putra, I Nyoman Darma. (2019)." Sastra Pariwisata: Pendekatan Interdisipliner Kajian Sastra dan Pariwisata", makalah untuk Seminar Nasional INO-Bali 2019 " Inovasi dalam Penelitian Sains, Teknologi dan Humaniora", dilaksanakan Universitas Dwijendra, 20 Desember 2019. 
Putra, I Nyoman Darma. (2020). "Ekspresi Romantik dan Kritik: Pariwisata Bali di Mata Empat Penyair Indonesia", Novi Anoegrajekti, Djoko Saryono, I Nyoman Darma Putra (eds.) Sastra Pariwisata, pp113134. Yogyakarta: Kanisius.

Rahmawati, Fitri Puji. (2017). Kepedulian Lingkungan dalam Nusantara Bertutur: Bentuk Penguatan Karakter dan Ekoliterasi Melalui Sastra Anak. The 1st International Conference on Language, Literature and Teaching 546.

Sarumpaet, Riris K. (2010). Pedoman Penelitian Sastra Anak. Jakarta: Yayasan Pustaka Obor Indonesia.

Smith, Valene L. 1989. Hosts and Guests: The Anthropology of Tourism. USA: University of Pennsylvania Press.

Suardika, I. K., \& Hafid, A. (2021). Peran Tradisi Lisan Iko-Iko Berbasis Sastra Melayu dalam Penguatan Komunitas Etnis Bajo. Mudra Jurnal Seni Budaya, 31(1). https://doi.org/10.31091/mudra.v31i1.251

Sudariyanto. (2019). Interaksi Sosial. Semarang: Penerbit Alprin.

Thompson, Carl. (2011). Travel Writing. New York: Routledge.

Tim Edukasi. (2020). Wisata Budaya di Indonesia. Yogyakarta: Sentra Edukasi Media.

Watson, J. Nicola (ed). 2009. Literary Tourism and Nineteenth-Century Culture. New York: Palgrave MacMillan.

Watson, J. Nicola. (2006). The Literary Tourist Readers and Places in Romantic \& Victorian Britain. New York: Palgrave MacMillan.

Wiyatmi. (2020). "Berwisata ke Lembata Melalui Cintaku di Lembata Karya Sari Narulita dalam Perspektif Sastra Perjalanan dan Kritik Sastra Feminis" dalam Novi Novi Anoegrajekti, Djoko Saryono, dan I Nyoman Darma Putra (Eds). Sastra Indonesia. Yogyakarta: Penerbit Kanisius bekerja sama dengan HISKI Komisariat Jember. 